Teamwork, Innovation, and Student Engagement in Technology Entrepreneurship - A Case Study

Dr. Anthony Joseph, Pace University 


\title{
Teamwork, Innovation, and Student Engagement in Technology Entrepreneurship - A Case Study
}

\begin{abstract}
Hardly any evidence exists to support purposeful innovation and entrepreneurship education specifically targeted to computing students in comparison to engineering students. Because computing is closely aligned with engineering in much theories and practices, it is reasonable to assume that the visions of future computing professionals would be similar to those of future engineers. Therefore, it is realistic to expect that while in college future computing professionals should at least be similarly educated and trained in business practices that expose them to entrepreneurship in the context of teamwork and innovation. This paper discusses the design, implementation, learning outcomes, and student engagement in a National Science Foundation funded technology entrepreneurship course offered in an urban university computing program. This course primarily focused on teamwork, innovation, and entrepreneurship. It sought to train students in becoming well-rounded business-minded technocrats grounded in disciplinary theories and technical skills as well as in innovative thinking, entrepreneurship, problem solving, teamwork, and communication skills. The course was supported by case studies of technology entrepreneurs as well as guest lecturers and mentors. The case studies mainly highlighted the experiences and advice of successful entrepreneurs through their business development ventures and problem solving strategies. The guest lecturers included both academic and non-academic professionals experienced in innovation and entrepreneurship. They provided the students with experiential knowledge and insights on teamwork, innovation, and entrepreneurship including specific examples of business problems encountered. The mentors were either technology entrepreneurs or senior level managers from industry versed in teamwork, innovation, and entrepreneurship; they assisted the student teams in financial or healthcare problem identification appropriately defined for solutions within the constraint of the semester; they further provided guidance, realism, and insight to the teams' ideas for a feasible problem solution. These interventions helped to supplement the content provided in the case studies and lectures. A central product of the course was the creation of a business plan developed to support an innovative problem solution to satisfy a financial or healthcare customer's need with its subsequent pitch. Students' performance in and enthusiasm for the course were generally positive as evidenced by the course grade percentage errors, learning performance indicators, interviews, and surveys. In addition, some of the products/services were judged by industry experts to be capable of satisfying the identified customer need if they were further developed. Nothing should be inferred from these results, however, because of the small sample size of 12 students, but the results seem to suggest that this approach to teaching teamwork, innovation, and entrepreneurship is meritorious in providing computing students with the professional skills needed for the global knowledge economy. The Technology Entrepreneurship course as described in this paper differs from most of the other related entrepreneurship courses in that it provided formal pedagogical instruction in teamwork, innovation, and entrepreneurship. Moreover, its assessment and evaluation included not only surveys, interviews, and performancebased assessment, but also journals as well as examinations.
\end{abstract}

\section{Introduction}


Hardly any evidence could be found in the literature to support the purposeful use of innovation and entrepreneurship instruction specifically targeted to computing education in the way that it exists for engineering education. The publication ${ }^{1}$, The Engineer of 2020: Visions of Engineering in the New Century, states that "[e]ngineering is a profoundly creative process", the engineering profession must "accommodate innovative developments from nonengineering fields", and that "[t]echnological innovations occur when a need arises or an opportunity presents itself". It further emphasized that these innovations "are occurring at an astonishing pace, especially those in information and communications technology....” Information and communications technology fields are also highly influenced by computing. To be able to adapt nonengineering innovations into engineering necessitates a "broadly educated" highly trained, and globally aware student of engineering who is continually immersed in life-long learning. This student of engineering is "the engineer of 2020"; one who is not only technically sound, but is also sufficiently sound in communication, leadership, and teamwork skills; liberal arts; social and health sciences; economics and business; and cross-cultural studies, having attributes such as "strong analytical skills, creativity, ingenuity, professionalism, and leadership.” Since engineering is a deeply creative process and the creative process can be categorized into five levels ${ }^{2}$ : (a) utilize one existing object without considering others, (b) choose one out of many objects, (c) make partial changes to a selected object, (d) develop a new object or completely modify the chosen one, and (e) develop an entirely new intricate system; each of these levels is further subdivided into six stages ranging from choosing the task to practical implementation ${ }^{2}$. Transformative technological innovations are more likely to occur at levels c through e; at these levels flexible innovative thinking ${ }^{3}$ with meaningful teamwork requiring teams to have the proper mix of technical or functional expertise, problem solving and decision making skills, and interpersonal skills $^{4,5}$ as well as be monitored and supported ${ }^{6}$ are essential.

Since computing is closely aligned with engineering in theory and practice, it is reasonable to assume that visions of future computing professionals would be similar to those spelled out for future engineers. Computing is a relatively young field with theories and the practices that are still evolving while its innovations in and transformations of other fields are occurring at an unpredictably fast rate. Some specialties in computing were borrowed from engineering (e.g., telecommunications and computer architecture), some computing disciplines are analogous to engineering ones (e.g. technology as in information technology), and some others could be classified as both computing and engineering (e.g., software engineering and computer engineering). Additionally, some computing departments are in engineering schools. Furthermore, in certain computing specialties such as cybersecurity, the practices have outpaced the development of governing theories. In addition, some examples of the fields transformed by computing include healthcare and medicine, business and economics, science, and engineering. Thus, computing and engineering are cross-fertilizing each other. The impact of computing on some fields might still be in its infancy.

Like engineering, computing is a very creative process involving innovative design that is conditioned by business, economic, social, political, ethical, and technical constraints ${ }^{1,3}$ generally within the setting of a team structure. Therefore, one could conclude that the computing professional should at least be educated and trained on a comparable level as the future engineer. One way to ensure that computing professionals are sufficiently well educated and trained in business and economics is to expose them to entrepreneurship education and training in the 
context of teamwork, creativity, and innovation while still in college. However, as stated by Doboli et $\mathrm{al}^{7}$, relatively "few entrepreneurship programs" exist that primarily target computing students. They reported that entrepreneurship in engineering curricula comes in upper level entrepreneurship engineering courses, certificate programs or minors in entrepreneurship, or integrative programs, and that most of these models were not solely offered in engineering schools. Most entrepreneurship "courses are targeted at business students”8.

Compared to the few entrepreneurship education and training programs within engineering schools for engineering students and others, fewer of these courses can be found in computing schools or specifically targeted to computing students, thereby disadvantaging computing students. Moreover, hardly any evidence could be found of formalized joint teamwork, innovation, and/or entrepreneurship instruction in computing or engineering curricula. Some examples of engineering and computing courses found are detailed in the next section, background and motivation.

The Technology Entrepreneurship course as described in this paper differs from most of the other related courses in that it provided formal pedagogical instruction in teamwork, innovation, and entrepreneurship. Like many other such courses it involved active entrepreneurs and senior managers from industry as well as included a business plan as part of the final deliverable. Instead of a product prototype, the student teams had to follow the generally accepted outline for business plan design as well as make reasonable assumptions and tradeoffs in their proposed product or service, and should address alternative competitive technical solutions to their financial or healthcare business solution while showing the relative competitive edge of their business over the competitors. Moreover, the assessment and evaluation of most of the courses cited in the literature included surveys, interviews, and/or performance-based assessment, but the assessment in the Technology Entrepreneurship course also included journals as well as examinations (six of them including the final exam) that focused on the knowledge and skills derived from the theoretical and experiential components.

\section{Background and Motivation}

In addition to present industry demand for mostly contract workers ${ }^{9}$, students are increasingly embarking on entrepreneurial ventures instead of pursuing regular employment ${ }^{10}$. Research on entrepreneurship revealed that over $6 \%$ of adults are creating new business enterprises ${ }^{11,12}$ in the United States, a country where a person is relatively more likely to engage in entrepreneurship activities and where companies with plenty employees of the entrepreneurial mindset tend to become more entrepreneurial $^{13}$. Moreover, the highest levels of entrepreneurial activity tends to be among individuals who are generally college educated ${ }^{12}$ and more specifically earned a specialized technological, professional, or business degree ${ }^{14,15}$. "Better-trained, more experienced entrepreneurs are less likely to fail."12 In addition, size does not define the level of entrepreneurialism within a company - an entrepreneurial company could be a large corporation or a reasonably small business. In fact, since the 1990's, larger corporations in the U. S. seeking to gain a competitive edge have been downsizing while small businesses have been creating new jobs - a net of over $80 \%{ }^{12}$. However, only “[a] small number of innovative start-ups account for a disproportionately large number of new jobs" ${ }^{13}$. Contemporaneously, many companies are laying off high-paid older workers with dated skills for those with current skills. Today's college graduates are entering a labor market that demands workers who are entrepreneurially minded 
and innovative thinkers with good problem-solving skills, strong communication skills, and adept teamwork skills. They must think like entrepreneurs capable of transferring knowledge and skills from one context to another even if they are merely regular employees, and as entrepreneurial employees, "[their] relationship skills are as important as [their] technical skills" " Therefore, "career success" is now not only directly dependent on the individual and the employer for which one works ${ }^{16}$, but also on the various teams of individuals with whom one works 9 .

Morris et $\mathrm{al}^{17}$ noted that the study of entrepreneurship as a discipline is relatively new. They asserted that "much of what constitutes the study of entrepreneurship today is borrowed or adapted from other disciplines.” Entrepreneurship emerged "as a business discipline” with theoretical underpinning from other disciplines including engineering, finance, psychology, sociology, anthropology, marketing, management, and organizational behavior. They further sought to build a holistic theory of entrepreneurship by integrating the available but seemingly unrelated body of research comprising 12 main "frameworks." Moreover, they identified the six main components of entrepreneurship to be entrepreneurial process, environment, entrepreneur, resources, business process, and organizational context with entrepreneurial process being the central one to which the other five components are inputs. Because entrepreneurship is a process, anyone can learn it $^{12,17}$. Similarly, innovative thinking and teamwork skills are learnable ${ }^{2,18,19,20}$. Research and empirical findings have established the value of teamwork in industry and academia in promoting improved quality performance, self-efficacy, and engagement ${ }^{4,5,21,22,23}$. These facts imply that one way to ensure that entrepreneurship, innovation, and teamwork education and practices are learnt is to teach them and subsequently assess for their learning. Some examples of engineering and computing courses that blend entrepreneurship, innovation, and professional skills education and training are the following:

The University of Nevada at Reno developed two senior level engineering capstone design courses that were cross-listed as a single course, which was open to MBA students ${ }^{24,25}$. The purpose of this cross-listed course was to produce business minded future engineers who through the experience of producing marketable products would develop better teamwork skills, adaptable communication skills, be comfortable with business plan development, and be knowledgeable of patents and intellectual property. Student team projects were either assigned or self-generated. The final product of the project was a functional product prototype supported by a written report describing its business and engineering aspects. The project evaluation was based on the intended business and engineering performance outcomes. The course grades comprised various performance-based assessments by faculty, students, and engineering practitioners.

The University of Puerto Rico at Mayaguez's Technology-Based Entrepreneurship interdisciplinary course ${ }^{26}$ sought to address industry's demand for potential engineers who are entrepreneurial and effective communicators with well-developed teamwork and decision-making skills within the framework of a four course series that also included the capstone design project course. Over 20 professors from engineering and business were involved in the course. Other key features of the course included idea generation and development mindful of engineering design as well as product development constrained by "technical feasibility” and marketability. Student teams chose their projects from the faculty assigned general theme, and the projects had to satisfy a niche market requirement as well as meet technical feasibility and economic viability criteria. The course assessment was multifaceted, continuous, and involved both faculty and students evaluating the course and each other. The course outcomes included in excess of 50 original product ideas, some of which were considered for patent.

Baylor University educating students in entrepreneurship stressed creativity and innovation education through the courses Electronic Design and Analysis and Design of Propulsion Systems ${ }^{27}$. The analysis and design of propulsion systems course was a team-oriented course that included three lessons devoted to creativity and 
innovation and requests for proposals. The teams' request for proposal projects' presentations were evaluated by a panel of professors while the written proposal was evaluated by the class instructor on the bases of creativity as well as communication skills. The project presentation and written report had equal weight in the students' grades, which also included in-class and final examinations.

Another course pertaining to engineering entrepreneurship, but targeting first-year engineering students, was offered by the School of Information Technology and Engineering at a mid-Atlantic university ${ }^{28}$. The aim was to assess students' engineering entrepreneurship perceptions within the context of a virtual information technology enterprise. In executing the project design in the virtual environment, students were exposed to many different fundamental engineering concepts from such disciplines as computer engineering, computer science, and systems. Evaluation and assessment were done by means of a pre/post-survey.

Stony Brook University’s inter-university Sensor Consortium for Medical and Sensor Systems central purpose was to provide entrepreneurship education to engineering and other technical students through a senior design entrepreneurship course within the context of medical and security sensor systems ${ }^{29}$. The course focused on product design and prototype development as well as business plan development. Each team final product was a functioning prototype supported by a technical proposal and report for customer presentation as well as a business plan. The course evaluation centered on the outcomes of the four recommended projects in a project competition, and participating students received two semesters of senior design course credit.

Two universities with entrepreneurship education targeted to computing students are Arizona State University Polytechnic campus and Hofstra University ${ }^{7,30}$. Arizona State University Polytechnic campus ${ }^{30}$ introduced entrepreneurship to computing students through two projects that involved active entrepreneurs in students' entrepreneurial activities. These projects stressed experiential learning of entrepreneurship through a myriad of activities and repeated interactions with entrepreneurs. The Hofstra University entrepreneurship in computing program also provided students with education in innovation and experiential learning in entrepreneurship ${ }^{7}$. Modules on entrepreneurship were added to existing required and elective courses in computer science and computer engineering. Local entrepreneurs, patent lawyers, and venture capitalists gave seminars and guest lectures on such topics as intellectual property, and their own professional experiences. In addition, a concentration and an option in Leadership and Innovation in Computing were developed with the option targeted to computer engineering students. The expected learning outcomes of the concentration and option included understanding the process of new business creation and financing; identifying and evaluating opportunities for new ventures; and becoming knowledgeable in intellectual property, marketing, and financial accounting. These outcomes were assessed via interviews and surveys.

Additional examples of entrepreneurship education directed to engineering and other technical students can be found in Standish-Kuon and Rice ${ }^{8}$ as well as in Creed et al ${ }^{31}$. These examples are generally similar to those outlined above in that they provided a strictly experiential approach to teamwork and innovation, mostly involved active entrepreneurs, and typically included a business plan in the final deliverables.

Most of these courses/programs were directed toward engineering students although two were developed specifically for computing students. Moreover, no course/program was found in the literature for computing students in computing education similarly designed as the course described in this paper. However, the Technology Entrepreneurship course of this study has elements of many of the courses reported above. Extensive searches conducted in Goggle and the Education Resources Information Center (ERIC) for 'entrepreneurship, creativity, innovation, and teamwork computing instructional programs' resulted in zero citations. However, in Google over 3200 citations were found for engineering and computer science publications that were related to one or more of the constructs but not all of them. Similarly, although the ERIC search on the same terms netted several hundred records relating to engineering or computer science higher education programs focused on entrepreneurship, creativity and/or innovation, no records 
referred to a comprehensive computing/computer science higher educational program comprising theoretical instruction and practical training in entrepreneurship, innovation, and teamwork.

\section{Course Design}

The design of the Technology Entrepreneurship course as reported in this paper shares some similarities with the example courses cited in the preceding section. It is also notably different in some important aspects. Like the example courses $8,24,25,26,27,28,29,30,31$, the Technology Entrepreneurship course sought to infuse innovative intelligence and an entrepreneurial attitude in technical education as well as provide students with the proper tools needed to identify and pursue real and potentially marketable business opportunities supported by effective business plans inclusive of business and technical details. It also included student teams for project assignments to help team members develop teamwork and flexible communication skills. Furthermore, like the Technology-Based Entrepreneurship course ${ }^{26}$ offered by the University of Puerto Rico at Mayaguez, the instructor in this course provided the student teams with the general framework for the project assignment with the constraint that the resulting product or service appealed to a niche consumer market. The project assignment required the student teams to investigate the local healthcare and financial industries and then identify a potential product, service, or process in either healthcare or finance for a niche consumer market that spanned beyond the local community. This approach allowed the different teams to come up with their own individual solutions to the identified problems. Like the Analysis and Design of Propulsion Systems course ${ }^{27}$ of Baylor University, this course provided formal lessons and assignments to students; albeit more, since the Analysis and Design of Propulsion Systems course seemed to have offered only three formal lessons relating to teamwork, innovation, and entrepreneurship while Technology Entrepreneurship offered formal lessons on these three topics - two lessons relating to teams and teamwork, three lessons relating to innovation inclusive of creativity, and seven lessons relating to entrepreneurship. Nonetheless, both courses offered formal instruction on creativity and innovation. Correspondingly, both courses included in-class and final examinations as well as they did not require any product prototype, but included judges external to the course and the course instructor to evaluate the final product. The final product/service of each team of the Technology Entrepreneurship course was a business plan of a financial or healthcare information technology company that accentuated the significance of its business concept supporting the conceived product or service developed at the algorithmic level. Like the senior design entrepreneurship course ${ }^{29}$ provided by the inter-university Sensor Consortium of Stony Brook University, the Technology Entrepreneurship course included and promoted interdisciplinary teamwork with business and technical students as well as business plan development and formal instruction on entrepreneurship topics. However, not all the teams in Technology Entrepreneurship included business students who were undergraduates; only two of the four teams did; and no team comprised both undergraduate and graduate students - the graduate students were paired separately. Although Stony Brook University's Sensor Consortium entrepreneurship course might have included computing students among the non-engineering technical students in the interdisciplinary teams, there was no evidence that it specifically targeted them. Like the entrepreneurship related courses expressly designed for and offered to computing students at Arizona State University Polytechnic campus, the Technology Entrepreneurship course also promoted experiential entrepreneurship training of students and their teams through repeated interactions with active entrepreneurs who served as mentors to the 
teams on the projects. In addition to active entrepreneurs, the Technology Entrepreneurship course also included senior managers from industry as mentors to student teams as the team identified, determined the scope, and developed its product, business concept, and business plan. Like the Hofstra University's entrepreneurship education for computing students ${ }^{7}$, guest lecturers were utilized to provide practical knowledge on and professional experiences in entrepreneurship - some of these guest lecturers were also active local entrepreneurs. Unlike the University of Nevada at Reno's cross-listed senior engineering capstone ${ }^{24,25}$ course that appeared to heavily depend on guest lecturers to provide the instruction on entrepreneurship, the Technology Entrepreneurship course used guest lecturers as a supplement to provide an experiential perspective to complement the theoretical perspective offered through class instruction.

As shown in the previous paragraph, the Technology Entrepreneurship course contained elements of several entrepreneurship related courses offered at different universities. One of its most distinguishing features is that it provided formal instruction on teamwork. Also, it supplemented formal lectures with case studies, guest lectures, and interviews to promote monitoring and supporting of students' teamwork ${ }^{6}$ required for in-class and out-of-class course related activities including the project as well as regular communications with the mentors on the progress of their respective teams on their product/service identification, scope, and development. In these regular feedback sessions with the teams, team members informed the instructor of the team's internal functioning as well as perceived performance and the instructor provided the team with feedback on its actual performance as well as appropriate encouragement for improving or sustaining its performance. The case studies were of entrepreneurs describing their business ventures, general experiences, and dispensing advice. These case studies were typically provided in the form of YouTube videos.

There were 12 students enrolled the Technology Entrepreneurship course; 10 were undergraduate students with two of them being business students and the others being computer science students; the remaining two were computer science graduate students. One computer science undergraduate student received an incomplete for the course for insufficient participation on his team project. The 12 students were grouped into four teams - three undergraduate teams and one graduate team. The undergraduate teams comprised of three and four undergraduate students with two of them being interdisciplinary. This is important because interdisciplinary teams facilitate enhanced student learning as well as complex problem solving in both academia and industry and the Accreditation Board for Engineering and Technology (ABET) Computing Accreditation Commission has stated that students should acquire operational goal-oriented teamwork skills as one of its student outcomes ${ }^{35}$. Some key concepts taught in this Technology Entrepreneurship course were teams, teamwork skills, team development, creativity and innovation, innovation algorithm, customer driven product identification and development, information technology business creation, market analysis, niche marketing and selling, and competitive business plans. In addition to the two textbooks and six reference books and magazines officially used in the course, relevant information from other popular magazines including The Economist was shared with the students. The two textbooks were McGraw Hill published Technology Ventures: From Ideas to Enterprise, $3^{\text {rd }}$ edition ${ }^{36}$, and the Technical Innovation Center published The Innovation Algorithm: TRIZ, Systematic Innovation and Technical Creativity, $2^{\text {nd }}$ edition ${ }^{2}$. The guest lectures were provided on innovation, design and 
development of a business plan, marketing and selling, and technology entrepreneurship in finance.

The course was assessed by means of surveys, individual and team interviews, journals, examinations, performance-based assessment, informal conversations with students and mentors, and email and oral feedback from mentors. The surveys included pre/post student assessment of their learning gains (SALG), peer evaluations, student course survey, and a monitoring and support protocol. Examinations included pre/post entrepreneur test as well as five in-class exams and a cumulative final exam. Two of the five in-class exams were team-based. The three monitoring and support surveys were used to aid and corroborate the interviews. The performance-based assessment used to assess and evaluate the final product/service submission in the form of a business plan was conducted with the help of a project score sheet and two judges from industry. Each student's course grade was evaluated based on the grade distribution of $16 \%$ for in-class exams, $24 \%$ for final exam, $10 \%$ for journal, $6 \%$ for class preparation and participation activities, $4 \%$ for student-mentor interactions, and $40 \%$ for the project (business plan and pitch). The assessment of this Technology Entrepreneurship course was multidimensional and relatively more extensive than that identified in any of the aforementioned courses. Moreover, Shartrand et $\mathrm{al}^{37}$ and Duval-Couetil et $\mathrm{al}^{38}$ reported that assessment of student learning in entrepreneurship educational experiences, especially in engineering have not been sufficiently well developed.

\section{Results}

From the surveys, interviews, examinations, and performance-based assessment, students reported and demonstrated important gains in the Technology Entrepreneurship course. In the Student Survey, most students rated the general categories of items (learning outcomes, teaching methods, instructional resources, and course impact) favorably. For example, for the four learning outcomes items and the three course impact items at least $67 \%$ of the students agreed or strongly agreed with these items. In fact $67 \%$ agreed or strongly agreed with course impact item, I discovered that team work helps get assignments completed quicker than working alone. Additionally, 100\% and $83 \%$ of the students agreed or strongly agreed with the item: As a result of taking this class I have a better understanding of entrepreneurs, and this item: The use of a journal in this course helped me to better assess my learning, respectively.

The journal was provided to students in a 14-item Microsoft Word template to help students with their learning of the course content through reflection upon it. It requested reporting on such items as the following:

- What have you learnt since your last journal entry and to what extent have you learnt it?

- Discuss the relationship between the concepts behind the materials learnt in this course with those covered in concurrent and previous courses as well as with other life experiences.

- $\quad$ Discuss your impression of the course in terms of your learning outcomes and preparation for related advance courses in your major and potential employment or graduate education.

- $\quad$ Time devoted to each of the following categories (individual class preparation, homework, project, meeting with professor, meeting with team members, meeting with mentor, use of library and Internet resources, and total time) per week. 
Students also rated each other in their journals on attendance at out-of-class meetings, preparation for in- and out-of-class meetings, positive contribution, respectful to others ideas, and flexibility. They typically rated each other with A's and B's, but mostly with A's on each of these five items. In the peer evaluation of team members via a team performance inventory, students rated each other under the general categories of results and productivity, team structure, team operation, and team skills on a scale of 0 to 4 with 4 being the highest and representing, [t] his aspect is well covered. The overall average rating from both graduate and undergraduate students was 3.20 with the undergraduate average rating being 3.08 and the graduate average rating being 3.31. A rating of 3 represents the following: We have mostly resolved but not all aspects of this factor.

On the pre- and post-SALG surveys ${ }^{39}$, there were 18 common Likert scale items. The scale answer options on the pre-survey were in the range of not applicable, not at all, just a little, somewhat, a lot, and a great deal. The overall number of students' responses on the pre-survey was 216 with 92\% reporting somewhat to a great deal (see Table 1). Moreover, an overall 27\% of student pre-survey responses indicated that they had a great deal of understanding, skills, attitudes, and abilities to integrate learning across contexts relative to Technology Entrepreneurship content and concepts. In the post-survey, there was an overall number of 212 responses with 79\% reporting moderate to great gains (see Table 2) on the Likert scale answer options of no gains, little gains, moderate gains, good gains, great gains, and not applicable to the items relating to the course. Students reported great gains in 52\% of their responses, which is about a 93\% relative change from the pre-SALG survey to the post-SALG survey. In addition to the Likert scale pre- post- survey items there were four open-ended items on both the pre- and post- surveys as well as an additional four open-ended items that were solely on the post-survey. The categories of questions students responded to are itemized in Table 3. Generally, the presurvey items asked students their expectations of the course, whereas the post-survey questions required students to assess their relative understanding, skills, abilities, attitudes, and learning transfer ability as a result of their course participation.

Table 1

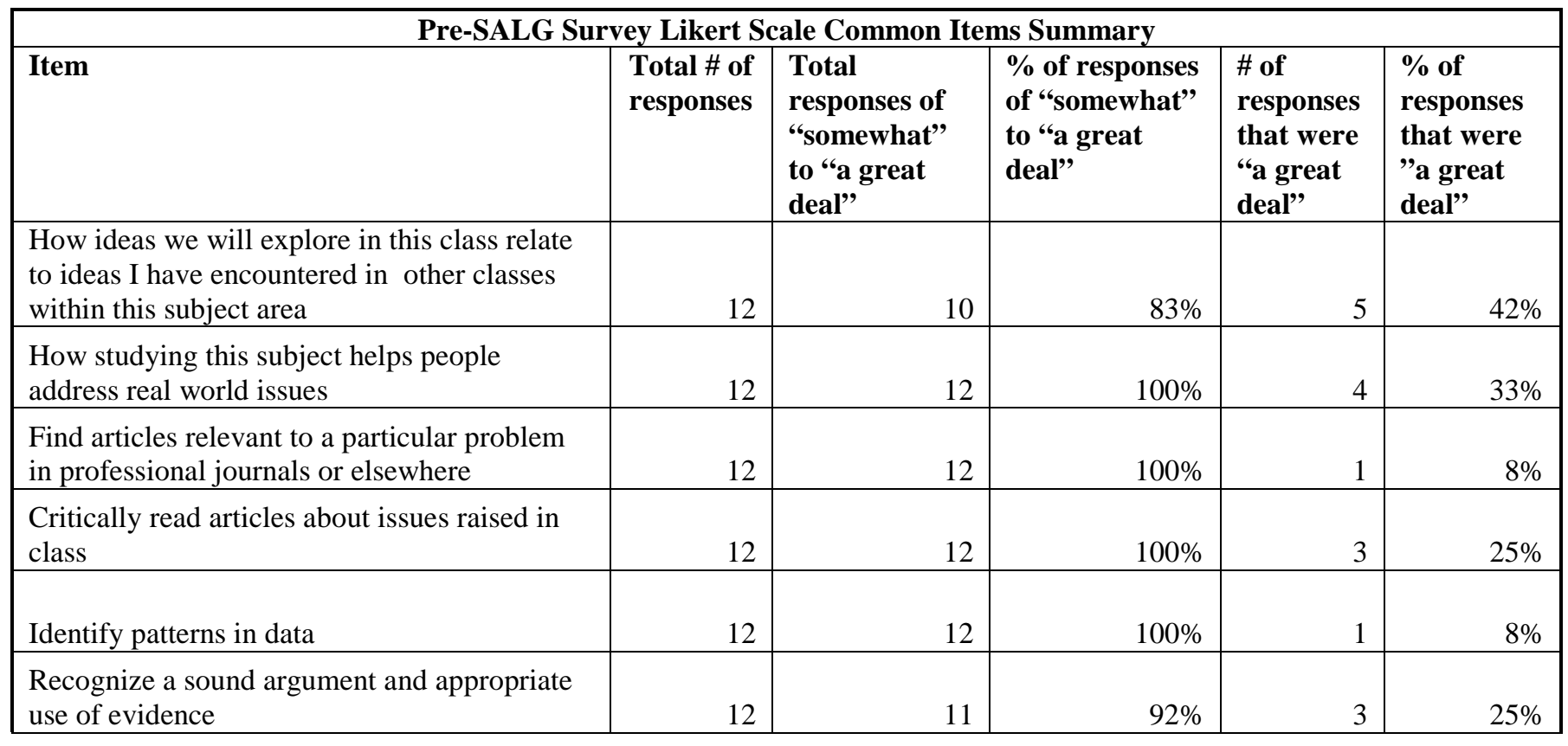




\begin{tabular}{|c|c|c|c|c|c|}
\hline Item & $\begin{array}{l}\text { Total \# of } \\
\text { responses }\end{array}$ & $\begin{array}{l}\text { Total } \\
\text { responses of } \\
\text { “somewhat” - } \\
\text { - “a great } \\
\text { deal” } \\
\end{array}$ & $\begin{array}{l}\text { \% of responses } \\
\text { of "somewhat" } \\
\text { to a great deal" }\end{array}$ & $\begin{array}{l}\# \text { of } \\
\text { responses } \\
\text { that were } \\
\text { "a great } \\
\text { deal" }\end{array}$ & $\begin{array}{l}\text { \% of } \\
\text { responses } \\
\text { that were } \\
\text { "a great } \\
\text { deal” } \\
\end{array}$ \\
\hline $\begin{array}{l}\text { Write documents in discipline-appropriate } \\
\text { style and format }\end{array}$ & 12 & 10 & $83 \%$ & 3 & $25 \%$ \\
\hline Work effectively with others & 12 & 11 & $92 \%$ & 4 & $33 \%$ \\
\hline Prepare and give oral presentations & 12 & 12 & $100 \%$ & 3 & $25 \%$ \\
\hline Enthusiastic about the subject & 12 & 12 & $100 \%$ & 4 & $33 \%$ \\
\hline Confident that I understand the subject & 12 & 9 & $75 \%$ & 1 & $8 \%$ \\
\hline Confident that I can do this subject & 12 & 12 & $100 \%$ & 4 & $33 \%$ \\
\hline Comfortable working with complex ideas & 12 & 8 & $67 \%$ & 5 & $42 \%$ \\
\hline $\begin{array}{l}\text { Willing to seek help from teachers when } \\
\text { working on academic problems }\end{array}$ & 12 & 11 & $92 \%$ & 6 & $50 \%$ \\
\hline $\begin{array}{l}\text { Connecting key ideas I learn in my classes } \\
\text { with other knowledge }\end{array}$ & 12 & 12 & $100 \%$ & 3 & $25 \%$ \\
\hline $\begin{array}{l}\text { Applying what I learn in classes to other } \\
\text { situations }\end{array}$ & 12 & 12 & $100 \%$ & 3 & $25 \%$ \\
\hline $\begin{array}{l}\text { Using systematic reasoning in my approach to } \\
\text { problems }\end{array}$ & 12 & 11 & $92 \%$ & 3 & $25 \%$ \\
\hline $\begin{array}{l}\text { Using a critical approach to analyzing data } \\
\text { and arguments in my daily life }\end{array}$ & 12 & 9 & $75 \%$ & 3 & $25 \%$ \\
\hline Grand Totals & 216 & 198 & $92 \%$ & 59 & $27 \%$ \\
\hline
\end{tabular}

Table 2

\begin{tabular}{|c|c|c|c|c|c|c|}
\hline \multicolumn{7}{|c|}{ Post-SALG Survey Likert Scale Items Summary } \\
\hline Item & $\begin{array}{l}\text { Total \# of } \\
\text { responses }\end{array}$ & $\begin{array}{l}\text { \# of Non- } \\
\text { responses }\end{array}$ & $\begin{array}{l}\text { Number of } \\
\text { "moderate" } \\
\text { to "great } \\
\text { responses" }\end{array}$ & $\begin{array}{l}\text { \% of } \\
\text { responses } \\
\text { that were } \\
\text { "moderate" } \\
\text { to "great" }\end{array}$ & $\begin{array}{l}\text { \# of } \\
\text { responses } \\
\text { that were } \\
\text { "great" }\end{array}$ & $\begin{array}{l}\text { \% of } \\
\text { responses } \\
\text { that were } \\
\text { "great" }\end{array}$ \\
\hline $\begin{array}{l}\text { How ideas from this class relate to ideas } \\
\text { encountered in other classes within the } \\
\text { subject area. }\end{array}$ & 12 & 0 & 12 & $100 \%$ & 5 & $42 \%$ \\
\hline $\begin{array}{l}\text { How studying this subject area helps } \\
\text { people address real world issues }\end{array}$ & 11 & 1 & 11 & $100 \%$ & 7 & $64 \%$ \\
\hline $\begin{array}{l}\text { Finding articles relevant to a particular } \\
\text { problem in professional journals or } \\
\text { elsewhere. }\end{array}$ & 12 & 0 & 9 & $75 \%$ & 3 & $25 \%$ \\
\hline $\begin{array}{l}\text { Critically reading articles about issues } \\
\text { raised in class }\end{array}$ & 12 & 0 & 9 & $75 \%$ & 4 & $33 \%$ \\
\hline
\end{tabular}




\begin{tabular}{|c|c|c|c|c|c|c|}
\hline Item & $\begin{array}{l}\text { Total \# of } \\
\text { responses }\end{array}$ & $\begin{array}{l}\text { \# of Non- } \\
\text { responses }\end{array}$ & $\begin{array}{l}\text { Number of } \\
\text { “moderate" } \\
\text { to “great } \\
\text { responses" }\end{array}$ & $\begin{array}{l}\% \text { of } \\
\text { responses } \\
\text { that were } \\
\text { "moderate" } \\
\text { to "great" }\end{array}$ & $\begin{array}{l}\text { \# of } \\
\text { responses } \\
\text { that were } \\
\text { "great" }\end{array}$ & $\begin{array}{l}\text { \% of } \\
\text { responses } \\
\text { that were } \\
\text { "great" }\end{array}$ \\
\hline $\begin{array}{l}\text { Writing documents in discipline- } \\
\text { appropriate style and format }\end{array}$ & 12 & 0 & 9 & $75 \%$ & 8 & $67 \%$ \\
\hline Identifying patterns in data & 12 & 0 & 11 & $92 \%$ & 5 & $42 \%$ \\
\hline $\begin{array}{l}\text { Recognizing a sound argument and } \\
\text { appropriate use of evidence }\end{array}$ & 12 & 0 & 10 & $83 \%$ & 8 & $67 \%$ \\
\hline Working effectively with others & 12 & 0 & 9 & $75 \%$ & 9 & $75 \%$ \\
\hline Preparing and giving oral presentations & 12 & 0 & 8 & $67 \%$ & 7 & $58 \%$ \\
\hline Enthusiasm for the subject & 12 & 0 & 11 & $92 \%$ & 8 & $67 \%$ \\
\hline $\begin{array}{l}\text { Confidence that you understand the } \\
\text { material }\end{array}$ & 12 & 0 & 11 & $92 \%$ & 7 & $58 \%$ \\
\hline Confident that you can do this subject area & 12 & 0 & 10 & $83 \%$ & 8 & $67 \%$ \\
\hline $\begin{array}{l}\text { Your comfort level in working with } \\
\text { complex ideas }\end{array}$ & 12 & 0 & 12 & $100 \%$ & 8 & $67 \%$ \\
\hline $\begin{array}{l}\text { Willingness to seek help from others when } \\
\text { working on academic problems }\end{array}$ & 12 & 0 & 11 & $92 \%$ & 6 & $50 \%$ \\
\hline $\begin{array}{l}\text { Connecting key class ideas with other } \\
\text { knowledge }\end{array}$ & 12 & 0 & 10 & $83 \%$ & 6 & $50 \%$ \\
\hline $\begin{array}{l}\text { Applying what I learned in class in other } \\
\text { situations }\end{array}$ & 11 & 1 & 9 & $82 \%$ & 5 & $45 \%$ \\
\hline $\begin{array}{l}\text { Using systematic reasoning in my approach } \\
\text { to problems }\end{array}$ & 11 & 1 & 9 & $82 \%$ & 5 & $45 \%$ \\
\hline $\begin{array}{l}\text { Using a critical approach to analyzing data } \\
\text { and arguments in my daily life }\end{array}$ & 11 & 1 & 7 & $64 \%$ & 6 & $55 \%$ \\
\hline Grand Totals & 212 & 4 & 167 & $79 \%$ & 110 & $52 \%$ \\
\hline
\end{tabular}

Table 3

\begin{tabular}{|l|l|}
\hline \multicolumn{2}{|c|}{ Pre- and Post-SALG Survey Comment Items } \\
\hline Pre- and Post- Survey Open-Ended Question Categories & Categories of Open-Ended Items Solely on Post-Survey \\
\hline Understanding of course content and concepts & Impact of graded activities and tests on learning. \\
\hline Couse related skills and abilities & Impact of class resources on learning. \\
\hline Attitudes toward course content, goals, and objectives & Class information impact on learning. \\
\hline $\begin{array}{l}\text { Integration of learning with other aspects of student life, job, } \\
\text { other courses, etc. }\end{array}$ & $\begin{array}{l}\text { Impact of support received from other class members on } \\
\text { learning. }\end{array}$ \\
\hline
\end{tabular}

The formal and informal meetings and interviews with students, teams, and mentors provided much useful information regarding monitoring, supporting, and managing the teams. The monitoring and support survey is one of the instruments that was used to facilitate student team interviews ${ }^{6}$. From time to time individual students would be asked about their team performance on the different class activities; each team was responsible for all assignments, except three individual exams and the final exam. The interviews were done to get an update on team performance outside the scheduled formal meetings. Some students reported on teammates not 
responding to their email correspondence or not attending planned meetings. In these cases, the professor would discuss the problem with the offending team member and work out a solution to the problem where feasible. For the formal interviews with the student teams, each team member would first fill out the monitoring and support survey of items to be discussed in each of the three scheduled interviews. Interview items included the medium used for team meetings, reason for team meetings, study of handout materials on teamwork and project management, judge journal assignments, and would you recommend working in teams. These interview items revealed that most of the team meetings were face-to-face or online and that these meetings were primarily to schedule work to be done on the project and the homework assignments. Very few team meetings were scheduled to include preparing for exams. Also very few students studied the handouts on teamwork and project management. Students and teams were informed of their class performance to date, provided mentors' feedback on their teams' engagement on the project, and encouraged to engage in good teamwork practices for skills development as well as to become more participatory in elements of the course where they needed to improve. The four mentors' (one for each team) feedback was obtained by means of email or face-to-face conversation. One of the mentors thought that the students in his team were thoughtful and engaged and that they considered such things as how they conceived their product and how that product solved a problem for consumers as well as costs and operations, which might seem obvious to an experienced entrepreneur, but are often ignored. He further posited that the course could be improved by helping the students to understand how best to utilize their mentor since he suggested [to his team] how they could leverage [his] skills, knowledge, and time, after the first valuable conversation, [and] they did not take advantage. Another mentor reported that interaction among team members in his team appeared to be low since he primarily interacted with one individual who happened to be the group leader and the driver for the project and they corresponded regularly. This mentor further stated that the exchanges in [his] view were mutually beneficial as we both conceptualized projects and directions that [he] was able to include in [his] own work.

Of the five in-class exams, two were team-based - exam 4 and 5. This was done to promote teamwork skills and team cohesion. In addition, there was a final exam and a pre- and postentrepreneur test. Using the percentage error formula adopted for students' performance on exams $^{6}$, an empirical true value of 89 was computed. The percentage error value indicates the measure of acceptable team performance required for team cohesion under the criteria that no team member's percentage error value for an exam grade be less than -10 points, all members of a team must have percentage error values within 15 points of each other, and each team member's percentage error value for an exam must be within \pm 10 points of the team's average percentage error value ${ }^{6}$, (see Table 4a). Exams 1 and 3 of undergraduate team 1 indicate limited team cohesion due to team member 3's relatively lower performance, but all other exams and the final exam show evidence of cohesion. Undergraduate team 3 seems to show the weakest performance of the teams as evidenced by having only one exam, exam 5, meeting the

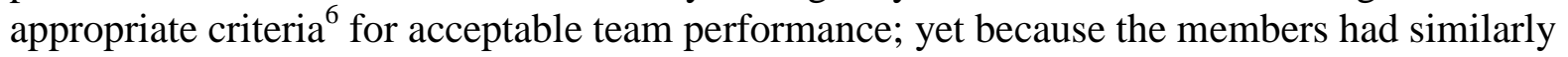
high and low performance across the exams, their average exam percentage error values met the acceptable team performance criteria, thereby demonstrating team cohesion. The team of graduate students showed the best performance in terms of percentage error values that met the criteria of acceptable performance required for demonstrating team cohesion. These team performances on the exams are substantiated by the academic performance indicator ${ }^{6}$ coded in 
binary that showed student learning outcomes from one exam to another over the duration of the course as shown in summarized form in Table 4b. This table substantiated that undergraduate team 1 and the graduate team experienced the most learning gains: 0.58 and 0.63 respectively. Undergraduate team 3 experienced the least learning gains. All teams’ performance decreased from the in-class exam average to the final exam average.

Table 4a

\begin{tabular}{|c|c|c|c|c|c|c|c|c|}
\hline \multicolumn{9}{|c|}{ PERCENTAGE ERRORS } \\
\hline \multirow{3}{*}{$\begin{array}{l}\text { TEAM } \\
\text { NUMBER }\end{array}$} & \multirow{3}{*}{$\begin{array}{l}\text { TEAM } \\
\text { MEMBER } \\
\text { NUMBER } \\
\end{array}$} & \multicolumn{7}{|c|}{ EXAMINATIONS } \\
\hline & & \multicolumn{5}{|c|}{ IN-CLASS } & \multirow{2}{*}{$\begin{array}{l}\text { IN-CLASS EXAM } \\
\text { AVERAGES }\end{array}$} & \multirow{2}{*}{$\begin{array}{l}\text { FINAL } \\
\text { EXAM }\end{array}$} \\
\hline & & Exam \#1 & Exam \#2 & Exam \#3 & Exam \#4 & Exam \#5 & & \\
\hline \multirow{3}{*}{$\begin{array}{l}\text { TEAM } \\
1 \text { UUG }\end{array}$} & 1 & 12 & 12 & 40 & 7 & 40 & 18 & 1 \\
\hline & 2 & 26 & 12 & 40 & 7 & 40 & 25 & 10 \\
\hline & 3 & 1 & 4 & -16 & 7 & 40 & 7 & 12 \\
\hline \multicolumn{2}{|l|}{ AVERAGE } & 13 & 9 & 22 & 7 & 40 & 17 & 8 \\
\hline \multirow{3}{*}{$\begin{array}{l}\text { TEAM } \\
\text { 2UG }\end{array}$} & 4 & 12 & -44 & 35 & 1 & 40 & 9 & 8 \\
\hline & 5 & -5 & -61 & -27 & 1 & 40 & -10 & -10 \\
\hline & 6 & 12 & 12 & 12 & 1 & 40 & 16 & 9 \\
\hline \multicolumn{2}{|l|}{ AVERAGE } & 7 & -31 & 7 & 1 & 40 & 5 & 2 \\
\hline \multirow{3}{*}{$\begin{array}{l}\text { TEAM } \\
\text { 3UG }\end{array}$} & 7 & 12 & -50 & 29 & 29 & 29 & 10 & -5 \\
\hline & 8 & 12 & -27 & 12 & 12 & 29 & 8 & 12 \\
\hline & 9 & -5 & -50 & 40 & 29 & 29 & 9 & -24 \\
\hline \multicolumn{2}{|l|}{ AVERAGE } & 7 & -42 & 27 & 23 & 29 & 9 & -5 \\
\hline \multirow[t]{2}{*}{ TEAM 1G } & 10 & 12 & 12 & 40 & 1 & 29 & 19 & 12 \\
\hline & 11 & -5 & 12 & 40 & 1 & 29 & 16 & 12 \\
\hline \multicolumn{2}{|l|}{ AVERAGE } & 4 & 12 & 40 & 1 & 29 & 17 & 12 \\
\hline
\end{tabular}

Table 4b

\begin{tabular}{|c|c|c|c|c|}
\hline \multicolumn{5}{|c|}{ Individual Teams Summary of Binary Codes } \\
\hline Type & Team 1UG & Team 2UG & Team 3UG & Team 1G \\
\hline Exam Losses & 0.33 & 0.25 & 0.33 & 0.25 \\
\hline Exam Gains & 0.58 & 0.50 & 0.33 & 0.63 \\
\hline
\end{tabular}

With regard to the pre-and post-entrepreneur test and the performance-based assessment, both undergraduate and graduate students showed relative gains from the pre-entrepreneur test to the 
post entrepreneur test ${ }^{39}$. The performance-based assessment was applied to the projects. Two external evaluators from industry assisted in the project evaluations presented in the form of a business plan for a product or service. Projects included a web-based music company that connects music lovers to the artist, prescription transaction machine designed to facilitate convenient prescription filling for the patient, Cold and Flu Lateral Flow Assay, and an Online Brokerage that provides financial information and decision making tools to the masses to help them with their trading decisions. These projects were judged for creativity, thoroughness, computational thinking, entrepreneurial skills, and presentation skills using a scoresheet adopted from the one used for annual New York City Science and Engineering Fair ${ }^{39}$. Some of the projects were judged worthy of further development and product implement. One such example was the prescription transaction machine; see Joseph ${ }^{39}$ for further details. All the projects were highly rated with a grade of at least $\mathrm{B}+$ and a separation of less than 10 points between highest average and the lowest average project grade.

\section{Discussion}

The results of the Technology Entrepreneurship course were generally positive. The project grades were within $10 \%$ of each other suggesting that the overall quality of the business plans for the conceived and developed products/services were essentially the same. The percentage error and the academic performance indicators showed that all the teams' performances went down from the average in-class exam grades to the final exam grades. Each team had a lower average percentage error for the final exam; undergraduate team 3 showed the worst overall performance with an average percentage error value of -5 -- only one team member's percentage error score was within $10 \%$ of it and no two members' percentage error scores were sufficiently close to provide evidence of team cohesion. The performance indicators also provided evidence of weak team cohesion for undergraduate team 3 by indicating that this team experienced the highest losses and lowest gains in learning from one in-class exam to another as well as the steepest decline in learning from the in-class exams average to the final exam. Undergraduate team 2 and the graduate team showed the lowest losses in learning from one in-class exam to another as well as the smallest decline in learning from the in-class exams average to the final exam with undergraduate team 2 having the very smallest decline. Furthermore, undergraduate team 1 and the graduate team showed the highest gains in learning from one exam to another with the graduate team showing the highest gains of any team. The team performance of undergraduate team 3 might have been hampered by their irregular team meetings, the less than 10 interactions they had, and the inflexibility within the team as reported in the team performance inventory for their peer evaluation. The other teams also had irregular team meetings and a limited number of interactions with each other. Nonetheless, the students generally reported that they like teams and would recommend working in teams to others.

In the pre/post SALG surveys, most students reported on the pre-survey that they were skilled in working effectively with others either somewhat, a lot, or a great deal, but on the post-survey nearly the same number of students (one less) reported that they made great gains in increasing their skills in working effectively with others. One student commented as follows on the postsurvey regarding working with others: My concept of working as a team has been significantly changed. Another student said the following: I have gained greater teamwork skills, and a greater way of seeing things in the world. In terms of changing attitudes, yet another student said that I originally thought you needed to be "born" an entrepreneur, not that you can learn to be 
one. A fourth student commenting on what he will carry into other classes or other aspects of life reported the following: I will carry my newfound organizational, teamwork and planning skills into my other classes. I will carry my newfound leadership skills and understanding of business into other aspects of my life. In general, students reported on the post SALG survey that their understanding of technology entrepreneurship was changed regarding teams or teamwork, entrepreneurs, and business ventures; they gained skills in leadership, motivation, taking charge, innovative or a different way of thinking, business knowledge, reliability, confidence, writing, teamwork, viewing problems as opportunities, problem solving, and entrepreneurship; they changed their attitudes towards entrepreneurship and the economy; and they will carry into other classes or other aspects of life teamwork, innovation, written plans, and problem solving. These are gains that students made by the end of the Technology Entrepreneurship course. Some students also liked the journal as evidenced in the following student comment: The journal assignment is probably one of the most unique and valuable traits to this class. It allows students to deep dive into self-analysis, something which most students rarely do. By writing in the journal weekly I have been able to identify areas where I can improve and quickly adapt to how I feel. In most scenarios, students won't realize what subject matter they are falling behind in until they take a test, once it is essentially too late. However, other students thought the journal was unnecessary as one student recommended less journals on the course student survey. Perhaps the results would have been more robust if there were more students in the sample.

\section{Conclusion}

A distinguishing feature of this technology entrepreneurship course is its formal teaching of teamwork, innovation, and entrepreneurship while supporting this formal instruction with experiential learning through mentors, case studies in YouTube videos, and guest lectures from practicing entrepreneurs and entrepreneurial business senior managers. When theory and practice are meaningfully integrated as in the interdisciplinary Technology Entrepreneurship course, the course achieves Nissani's ${ }^{32}$ "condition of coherence: the blending of elements is not random, but helps to endow knowledge, research, or instruction with meaningful connections and greater unity”. Moreover, Bransford et $\mathrm{al}^{33}$ stressed the importance of learning transfer across spheres of knowledge to enable understanding; therefore, central to students' interdisciplinary work is support in becoming metacognitive learners ${ }^{34}$. This was achieved in the Technology Entrepreneurship course by providing students with theoretical and experiential opportunities to work on open-ended team-based projects in finance or healthcare under the supervision of mentors and the instructor as well as to reflect on these activities through assignments, written assessments, journals, and interviews. Although the teams did not function optimally, most teams showed at least satisfactory levels of team cohesion and the students reported many gains on the post-SALG survey including such examples as teamwork, problem solving, innovative thinking, entrepreneurship, and leadership. However, it should be noted that because of the small sample size which makes this study exploratory, the approach herein to teaching teamwork, innovation, and entrepreneurship skills needs to be replicated with a larger sample size of 30 or more students to determine the efficacy of the results obtained and the inferences that can be made.

\section{Acknowledgment}

This material is based upon work supported by the National Science Foundation under Grant Number: 0942732 


\section{Disclaimer}

Any opinions, findings, and conclusions or recommendations expressed in this material are those of the author and do not necessarily reflect the views of the National Science Foundation.

\section{References}

1. Committee on the Engineer of 2020, The Engineer of 2020: Visions of Engineering in the New Century, Washington, DC: The National Academies Press, 2004.

2. Altshuller, G., The Innovation Algorithm: TRIZ, Systematic Innovation and Technical Creativity, $2^{\text {nd }}$ Edition, Worcester, MA: Technical Innovation Center, 2007.

3. Weiss, D. and Legrand, C., Innovative Intelligence: The Art and Practice of Leading Sustainable Innovation in Your Organization, Ontario, Canada: John Wiley \& Sons, 2011.

4. Katzenbach, J and Smith, D., The Wisdom of Teams: Creating the High Performance Organization, Boston, MA: Harvard Business School Press, 1993.

5. Smith, K. and Imbrie, P., Teamwork and Project Management, $3^{\text {rd }}$ Edition, New York, NY: McGraw-Hill, 2007.

6. Joseph, A. and Payne, M., "Efficacy of Monitoring and Supporting College Students Teamwork: A Case Study,” The International Journal of Learning, Vol. 18, No. 9, 2012, pp. 223-240.

7. Doboli, S., Kamberova, G., Impagliazaao, J., Fu, X., and Currie, E., "Model of Entrepreneurship Education for Computer Science and Computer Engineering Students," Proceedings of the $40^{\text {th }}$ ASEE/IEEE Frontiers in Education Conference, October 27-30, 2010, pp. T1B1-T1A-7. Retrieved 12/31/12: http://people.hofstra.edu/Xiang_Fu/XiangFu/publications/simonav2.pdf.

8. Standish-Kuon, T. and Rice, M., "Introducing Engineering and Science Students to Entrepreneurship: Models and Influential Factors at Six American Universities,” Journal of Engineering Education, January, 2002, pp. 3339.

9. Glen, P., “Build Relationships, and Opportunities will Follow,” Computerworld, December 17, 2012, pp. 28.

10. Charney, A. and Libecap, G., Impact of Entrepreneurship on Education, Kauffman Center for Entrepreneurial Leadership, 2000. Retrieved 10/10/12: http://www.unm.edu/ asalazar/Kauffman/Entrep_research/e_ed_grow.pdf.

11. Reynolds, P., Carter, N., Gartner, W., Greene, P., Cox, L., The entrepreneur next door: characteristics of individualized starting companies in America - An executive summary of the panel study of entrepreneurial dynamics, Kauffman Foundation, 2002. Retrieved 10/09/12: http://energizingentrepreneurs.org/content/cr_5/2_000060.pdf.

12. Zimmerer, T. and Scarbborough, N., Essentials of Entrepreneurship and Small Business Management, $3^{\text {rd }}$ Edition, Upper Saddle River, NJ: Pearson Prentice Hall, 2002.

13. The Economist, “Global Heroes: A Special Report on Entrepreneurship,” The Economist Magazine, March 14, 2009, pp. 1-20.

14. Minnitti, M. and Bygrave, W., Global Entrepreneurship Monitors National Entrepreneurship Assessment -United States of America: 2003 Executive Report, Babson College and Kauffman Foundation, 2004. Retrieved 3/14/08: http://www.kauffman.org.

15. Henricks, M., “Best Practices,” Entrepreneur, October, 2004, pp.84-87.

16. Chen, Y., "Career Success of Knowledge Workers: The Effects of Perceived Organizational Support and Person-Job Fit,” iBusiness, Vol. 2, 2010, pp. 389-394.

17. Morris, M., Kuratko, D., and Schindehutte, M., "Towards Integration: Understanding Entrepreneurship through Frameworks," Entrepreneurship and Innovation, February 2001. pp. 35-49.

18. Weiss, D. and Legrand, C., Innovative Intelligence: The Art and Practice of Leading Sustainable Innovation in Your Organization, Ontario, Canada: John Wiley \& Sons, 2011. 
19. Dunne, E. and Rawlins, M., "Bridging the Gap between Industry and Higher Education: Training Academics to Promote Student Teamwork," Innovations in Education and Training International, Vol. 37, No. 4, 2000, pp. 361-371

20. Riebe, L., Roepen, D., Santarelli, B., and Marchioro, G., "Teamwork: Effectively Teaching an Employability Skill," Education + Training, Vol. 52, no. 6/7, 2010, pp. 528-539.

21. Stump, G., Hilpert, J., Husman, J., Chung, W., and Kim, W., "Collaborative Learning in Engineering Students: Gender and Achievement," Journal of Engineering Education, July 2011, pp. 475-497.

22. Wilson, P., "Mutual Gains from Team Learning: A Guided Design Classroom Exercise," Review Agricultural Economics, Vol. 27, No. 2, 2005, pp. 288-296.

23. Lightner, S., Bober, M., and Willi, C., “Team-Based Activities to Promote Engaged Learning,” College Teaching, Vol. 55, no. 1, 2007, pp. 5-18.

24. Kleppe, J. and Wang, E., “Teaching Invention, Innovation, Entrepreneurship in Engineering,” Retrieved 12/31/12: http://www.nciia.net/proceed_01/Kleppe-Wang\%20handouts.pdf.

25. Looney, M. and Kleppe, J., “Entrepreneurship in Electrical Engineering Education,” Proceedings of the 1996 IEEE Frontiers in Education, pp. 707-710. Retrieved 12/31/12: http://fie-conference.org/fie96/papers/262.pdf..

26. Torres, M., Vélez-Arocho, J., and Pabón, J., "BA 3100 - Technology-Based Entrepreneurship: an Integrated Approach to Engineering and Business Education," Proceedings of the 1997 IEEE Frontiers in Education Conference, November 5-8, 1997, pp. 738-743.

27. Van Treuren, K., Jean, B., and Fry, C., “Teaching Creativity and Innovation in the Classroom,” American Society for Engineering Education, 2012. Retrieved 12/31/12: http://www.asee.org/public/conferences/8/papers/3830/download.

28. Dabbagh, N. and Menascé, D., "Student Perceptions of Engineering Entrepreneurship: An Exploratory Study," Journal of Engineering Education, April 2006, pp. 153-164.

29. Luryi, S., Tang, W., Lifshitz, N., Wolf, G., Doboli, S., Betz, J., Maritato, P., and Shamash, Y., "Entrepreneurship in Engineering Education," Proceedings of the $37^{\text {th }}$ ASEE/IEEE Frontiers in Education Conference, October 10-13, 2007, pp. T2E-10-T2E-15. Retrieved 1/3/13: http://www.fieconference.org/fie2007/papers/1705.pdf.

30. Gary, K., Razdan, A., Koehnemann, H., Sannier, A., and Kagan, A., "Work-in-Progress: Embedding Entrepreneurship in Computing Curricula," Proceedings of the 38th ASEE/IEEE Frontiers in Education Conference, October 22-25, 2008, pp. S2G-7- S2G-8.

31. Creed, C., Suuberg, E., and Crawford, G., "Engineering Entrepreneurship: An Example of a Paradigm Shift in Engineering Education,” Journal of Engineering Education, April, 2002, pp. 185-195.

32. . Nissani, M., "Fruits, Salads, and Smoothies: A Working Definition of Interdisciplinarity,” Journal of Educational Thought, Vol. 29 No. 2, 1995, pp. 121-128.

33. Bransford, J., Brown, A., Cocking, R., Donovan, M., and Pellegrino, J., How People Learn: Brain, Mind, Experience, and School, expanded edition. Washington, D.C.: National Academy Press, 2000.

34. Bradbeer, J., “Barriers to Interdisciplinarity: Disciplinary Discourses and Student Learning,” Journal of Geography in Higher Education, Vol. 23, No.3, 1999, pp.381-396.

35. ABET Computing Accreditation Commission, Criteria for Accrediting Computing Programs, Baltimore, MD: ABET, 2012. Retrieved 1/14/12: http://www.abet.org/accreditation-criteria-policies-documents/

36. Byers, T., Dorf, R., and Nelson, A., Technology Ventures: From Idea to Enterprise, $3^{\text {rd }}$ Edition, New York, NY: McGraw-Hill, 2011.

37. Shartrand, A., Besterfield-Sacre, M., Olds, B., Weilerstein, P., “Assessing Student Learning in Technology Entrepreneurship," Proceedings of the $38^{\text {th }}$ ASEE/IEEE Frontiers in Education Conference, October 22-25, 2008, pp. F4H-12-F4H-17.

38. Duval-Couetil, N., Reed-Rhoads, T., and Haghighi, S., "Development of an Assessment Instrument to Examine Outcomes of Entrepreneurship Education on Engineering Students," Proceedings of the $40^{\text {th }}$ ASEE/IEEE Frontiers in Education Conference, October 27-30, 2010, pp. T4D-1-T4D-6.

39. Joseph, A., "Influence of Entrepreneurial Aptitude on Technology Entrepreneurship Course Performance," Proceedings of the 2013 ASEE/IEEE Frontiers in Education (FIE) Conference, October 23-26, 2013, pp. 13991405. 